\title{
Passive, Victims or Unintended Misrepresentation?
}

\author{
Fidel C. T. Budy ${ }^{1}$ \\ ${ }^{1}$ Department of Geography and Earth Sciences, Aberystwyth University, Penglais, Aberystwyth, UK \\ Correspondence: Fidel C. T. Budy, Department of Geography and Earth Sciences, Aberystwyth University, \\ Penglais, Aberystwyth, SY 23 3DB, United Kingdom. Tel: 44-77-5915-2135. E-mail: fidelbudy@gmail.com
}

Received: April 11, 2021

doi:10.5539/jsd.v14n4p13
Accepted: May 23, $2021 \quad$ Online Published: May 26, 2021

URL: https://doi.org/10.5539/jsd.v14n4p13

This work was supported by the European Research Council (grant number 339567).

\begin{abstract}
Sustainable development efforts to mitigate the challenges that women face in the midst of land grabbing could be significantly undermined or they could fail to address the concerns of rural African women if they are not driven by the everyday lived experiences of rural African women. Evidence suggests that current accounts of how rural African women experience land grabbing oversimplify the homogeneity of their experiences, depicting them as entirely passive and victims who lack the agency to react to the loss of their land. Addressing this gap in our appreciation of the impact of land grabbing on rural African women is significant to ensure equal access to land and secure tenure rights for women actually work. To this end, there are some in the literature that have, and continue to challenge the depiction of rural African women as entirely passive and victims, lacking agency. This paper builds on those studies to expand the parameter of inquiry by bringing fresh perspectives to the debate from Senjeh District in Liberia. Utilising data collected through qualitative semi-structured interviews in the district over a period of four months, this paper argues that there is a divergence between the well held notions by the literature and experts on the one hand and, women in Senjeh on the other hand. The paper also argues that rural women in Senjeh District exhibited various agency in multiple ways against the loss of their land to Sime Darby.
\end{abstract}

Keywords: rural African women, Senjeh district, land grabbing, reactions from below, sustainable development

\section{Introduction}

To achieve sustainable development in rural African communities, many have called for legal protections, equal and secure land rights for rural African women to land within rural spaces (Chu, 2011; De Schutter, 2011; Wisborg, 2013; Verma, 2014; Archambault \& Zoomers, 2015; Hall, Edelman, Borras, Scoones, White \& Wolford, 2015; Nyantakyi-Frimpong \& Bezner-Kerr, 2016). Most of the calls to action and mitigation strategies to ensure equal protection for women in rural African spaces are based on the notion that rural African women are experiencing the negative impacts of land grabbing worse than men (Razavi, 2003; Cotula, Vermeulen, Leonard \& Keeley, 2009; De Schutter, 2009; Vermeulen \& Cotula, 2010; Mutopo, 2011; Daley \& Pallas, 2013; Mutopo \& Chiweshe, 2014; Verma, 2014; Martiniello, 2015; Murphy, Carmody \& Okawakol, 2017; Ryan, 2017). As such, calls for deeper conversations about the current ways that large-scale land deals are envisaged as it relates to the unequal impacts on women have been largely catered to in the large body of work on the socioeconomic impacts of land grabbing in rural Africa (De Schutter, 2011; Knight, Adoko, Auma, Kaba, Salomao, Siakor \& Tankur, 2012; Cotula, 2013; Boamah, 2014; Gilfoy, 2014; Verma, 2014; Archambault \& Zoomers, 2015; Hall et al., 2015; Martiniello, 2015; Ryan, 2017). Relatedly, one of the main mitigation strategies being advocated for by critics of the uneven distribution of the benefits and the negative outcomes of the deals is giving women seats at discussion tables convened for the negotiation of large-scale land deals and, direct access to the benefits of those land deals once they become operational (Chu, 2011; Lund, 2011; Behrman, Meinzen-Dick \& Quisumbing, 2012; Verma, 2014). This, some believe, would contribute not only to the sustainable development needs of women but rural communities in general (Chu, 2011; Unruh, 2009).

Some, such as Borras, Franco and Wang (2013) and De Schutter (2011) have gone as far as suggesting that the plight of rural African women in the midst of the land grabbing phenomenon should be considered as a human rights violation against women. Linked to that is the fact that most of the current accounts discussing the negative experiences of rural African women in the midst of losing land to land grabbers, cite rural patriarchal cultural 
structures as one of the main factors for why women are experiencing the negative impacts of land grabbing worse than men (Daley \& Pallas, 2013; Gilfoy, 2014; Verma, 2014; Ryan, 2017; Damtew, 2019). These cultural structures, as some argue, contribute to the notion that rural African women experiencing the negative impacts of land grabbing are passive victims who lack the agency to react against land grabbers, rural elites or other powerful members within their communities (Chu, 2011; Knight et al., 2012; Gilfoy, 2014; Peemans, 2014; Hall et al., 2015; Murphy et al., 2017; Damtew, 2019; Tzouvala, 2019).

Whilst the current accounts of the experiences of rural African women in the midst of land grabbing must be commended, there are criticisms of its oversimplification of the plight of rural African women (Moreda, 2015; Vieri \& Calabro, 2019). This means that there are still gaps in our current appreciation of rural African women's experiences of land grabbing (Hall et al., 2015; Ndi, 2019). For example, most of the current studies depicting women as passive and victims had been conducted from afar, through quick and dirty approaches or have privileged expert knowledge over those of the rural women being impacted by the phenomenon (Edelman, 2013; Oya, 2013; Hall et al., 2015). Limited or no attention is given to the endogenous knowledge of women whose everyday lived experiences are being impacted by the phenomenon. Missing the endogenous voices of women in developing mitigation strategies, such as legal protections and secure land rights, could undermine those sustainable development efforts and further exacerbate the current plight of rural African women (Edelman, 2013; Oya, 2013; Gilfoy, 2014; Corson, Brady, Zuber, Lord \& Kim, 2015; Gingembre, 2015; Larder, 2015; Edelman \& Borras, 2016). Consequently, there is a growing body of studies that are challenging the notion that women who lose land in rural Africa to land grabbing are passive and victims who lack agency (Boamah, 2014; Hall et al., 2015; Martiniello, 2015; Moreda, 2015; Ndi, 2019; Budy, 2020). This paper will build on those studies challenging the notion that rural African women who lose control over their land are passive and victims by bringing fresh perspectives to the debate from Senjeh District in Liberia. In doing so, this paper seeks to make an empirical contribution to knowledge by expanding the parameters of inquiries into the experiences of rural African women when reacting against the loss of control over land in rural spaces.

The arguments in this paper are based on empirical evidence gathered over a period of four months in Senjeh District in Liberia. The case study involved Sime Darby - a Malaysian oil palm company. The company signed a 63-years lease agreement with the Liberian government for over 300,000 hectares of rural land spread across four western and central counties in Liberia including land in Senjeh District in 2009 (Siakor, 2012; Chapelle, 2014; Gilfoy, 2014). Whilst the company claimed to have consulted and compensated residents, many residents had been agitating against the company for what they argued was the mismanagement of the compensation scheme as well as failure to keep developmental promises made during the consultation phase (Siakor, 2012; Gilfoy, 2014). Privileging the endogenous voices of residents in the district, especially women, this paper will make two arguments. Firstly, the paper will argue that there is a divergence between the dominant notions in the literature, and held by experts, that rural women are passive victims who lack agency on the one hand and, rural women in Senjeh District on the other. Secondly, the paper will argue that women in Senjeh District demonstrated a variety of agency through multiple ways in response to the loss of their land to the Sime Darby oil palm company.

In order to present the premises in support of the key arguments of this paper, the paper is divided into eight sections. The next section is a critical review of the relevant literature on the impact of losing control over their land on rural African women. Section two begins with definitions of key concepts used in this paper. Section three of this paper is a brief description of the methodology of the research conducted for this paper including legal and ethical considerations. Sections four, five, six and seven present separate arguments in support of the two main arguments mentioned above. The final section of this paper is the conclusion, which summaries the key arguments, limitation of the paper and recommendation for future research.

\section{Gendered Experiences of Land Grabbing in Rural Africa}

Agency is a concept that has an elusive and vague characteristic (Burke, 2012). It is a central component in development and empowerment research but it is inherently problematic to fully measure or understand (Daley \& Pallas, 2013; Verma, 2014). In gender perspectives, particularly those within the broader feminist development and empowerment literature, and land grabbing literature in particular, agency encompasses women's participation in household decision-making, freedom of mobility and association (Archambault \& Zoomers, 2015; Martiniello, 2015). It is also about their uncontrolled participation in the decisions about land concessions, uses of rental fees received as well as developmental benefits that are requested by rural residents who lose their land to large-scale concessions (Chu, 2011; Verma, 2014). In contrast to some notions in the literature that women in particular and rural people in general lose their agency with the loss of their land to concessionaires, retained agency is the concept that whilst they might lose control over the land they retain control over other aspects of decision-making about their social, economic and political experiences (Gingembre, 2015; Larder, 2015; Ryan, 2017; Budy, 2020). 
Agency in this paper is articulated in many ways. Scholars have confirmed four main approaches to understanding agency: resistance, empowerment, instrumental and compliant (Burke, 2012). Resistance agency is where the actor demonstrate their agency in resisting a phenomenon or action (Hartman, 2007). Empowerment agency is where the actor utilise their negative experience to empower them to take actions in other ways (Wolkomir, 2004). Instrumental agency would be where the loss of land to a concession company is used as an instrument to take advantage of other opportunities (Mir, 2009). An example would be gaining wage employment with the company taking control over the land. Compliant agency is where women exhibit agency in the ways that they choose to conform to their environment (Bilge, 2010). In terms of other concepts used in this paper, endogenous refers to anything that origins from within (Peemans, 2014; Malunga \& Holcombe, 2016). As such, endogenous voices thus refer to the views and perspectives of those originating from Senjeh District where the research for this paper was conducted. Dichotomously, exogenous refers to anything that originates from outside the district or Liberia in general (Peemans, 2014).

Turning our attention to the land grabbing literature, we find that rural people in Africa who lose their land to largescale land concessionaires are depicted as homogenous, passive and victims (GRAIN, 2008; Cotula et al., 2009; Elhadary, 2010; Mutopo, 2011; Knight et al., 2012; Siakor, 2012; Daley \& Pallas, 2013; Mutopo \& Chiweshe, 2014; Hausermann et al., 2018). Challenges to that notion have been growing with specific new bodies of literature within the wider land grabbing debate, such as literature on the political reactions from below to land grabbing (Tsikata \& Yaro, 2014; Corson et al., 2015; Gingembre, 2015; Hall et al., 2015; Larder, 2015; Martiniello, 2015; Moreda, 2015). These studies have challenged the notion that rural people lack agency and have provided robust evidence to show that rural people are heterogeneous, retain agency and are reacting against the loss of their land within the land grabbing framework (Gingembre, 2015; Hall et al., 2015; Larder, 2015; Moreda, 2015). Whilst there has been some progress in general, there is still a lot to be done when it comes to the plight of rural African women (Chu, 2011; Hall et al., 2015; Verma, 2014; Moreda, 2015; Ryan, 2017).

In most of the current literature on the impacts of land grabbing on rural livelihoods, agency, land rights and identity politics in Africa, women are largely, still, being depicted as passive, victims and lacking agency whether within their homes or against land grabbers (White, 2012; Daley \& Pallas, 2013; Gilfoy, 2014; Verma, 2014; Ryan, 2017). For example, as Ritu Verma (2014) argues, when large-scale land deals are being negotiated with multinational businesses, rural elites and men are those that are consulted and compensated, whilst women are left out, something that undermines rural development efforts. This is not a notion that is isolated (Chu, 2011; Lund, 2011; Cotula, 2013; Daley \& Pallas, 2013; Doss, Summerfield \& Tsikata, 2014; Gilfoy, 2014; Martiniello, 2015). In fact, many in the literature argue that this is true in most cases of land grabbing across the continent (Vermeulen \& Cotula 2010; Chu, 2011; De Schutter, 2011; Borras et al., 2013; Gilfoy, 2014; Fonjong, Sama-Lang, Fombe \& Abonge, 2016; Nyantakyi-Frimpong \& Bezner-Kerr, 2016). Furthermore, the notion that women are not consulted or compensated when they lose land is usually framed within the concept of rural patriarchy (Gilfoy, 2014; Verma, 2014; Ryan, 2017). Within the framework of rural patriarchal structures when land is lost and available land become scarce, women are pushed further onto the margins of land access as even kinships are strained due to the scarcity of land (Burns, Gleadow, Cliff, Zacarias \& Cavagnaro 2010; Knight et al., 2012; Cotula, 2013; Verma, 2014). As such women tended to struggle to sustainably meet their livelihood needs including having to travel long distances away from their towns and villages to find firewood for heating their homes and cooking (Chu, 2011; Daley \& Pallas, 2013; Ryan, 2017). Furthermore, there are multiple other ways that women in rural African communities are experiencing the negative impacts of land grabbing including being thrust into taking on greater responsibilities to support their families (Haywood, Maltitz, Setzkorn \& Ngepah, 2008; Chu, 2011; De Schutter, 2011; Behrman, Meinzen-Dick \& Quisumbing, 2012; Daley \& Pallas, 2013; Ossome, 2014; Ryan, 2017). Where job opportunities are available to women, these are usually temporary and they are underpaid (Cotula, 2013; Wisborg, 2013; Murphy et al., 2017).

Notwithstanding the above, within the land grabbing debate, there is a growing body of literature on reactions to land grabbing from below, in which women are being presented in a different light (Boamah, 2014; Hall et al., 2015; Martiniello, 2015; Moreda, 2015; Ryan, 2017; Budy, 2020). For example, Martiniello (2015), presented evidence from the Amuru District in northern Uganda where a group of between 80 and 100 women stripped naked and blocked planned evictions from land to which they had ancestral ties and also depended on for their livelihood needs. According to Martiniello (2015) the government of Uganda had awarded the land to the Madhvani Group, which triggered the reaction from the women to halt the land deal. Also, in an earlier study by Unruh (2009), he presented evidence of how a group of female lawyers in Liberia had worked to pass a law that would reverse the patriarchal control of land inheritance affecting mostly rural women married under customary law. According to the study, due to the new law, rural women in Liberia could now have claims to the estates of their late husbands 
including to their land (Unruh, 2009).

The agency of women in the midst of land grabbing has also been considered adjacent to rural migration. As Archambault and Zoomers (2014) argue, when men migrated from rural places to other rural places and some urban places in search for jobs due to the loss of land in their home towns, women were thrust into the role of taking on extra responsibilities to support the families whilst the men were away. These included cultivating the scarcely available family plot or managing money that the migrating men sent back to their families (Archambault \& Zoomers, 2014). Whether, through direct political reactions from below against land grabbing or indirectly demonstrating retained agency in the midst of losing control over land within rural African communities, women are clearly, not entirely passive, victims or lacking agency (Martiniello, 2015; Moreda, 2015; Ryan, 2017; Budy, 2020). Yet, as Hall et al. (2015) suggest and echoed by Edelman and Leon (2016), whilst there are studies that have flagged the issue of gender, especially as it relates to women, most of what we see is focused on gendered impacts and vulnerabilities as I have discussed so far and not on gendered agency, responses and resistance. This paper will make a contribution to filling that gap by addressing the gendered reactions to land grabbing from below. To clarify, political reactions from below or reactions from below is adopted from the framing by Hall et al. (2015), in which it refers to responses that extend far beyond mere resistance.

What is clear in the literature is that the depiction of rural African women as passive, victims or lacking agency is a disservice to them (Boamah, 2014; Tsikata \& Yaro, 2014; Martiniello, 2015; Ryan, 2017; Budy, 2020) It also has the propensity of advocating for mitigation efforts that do not address the actual concerns of rural African women, which could undermine sustainable development efforts to promote equitable experiences of land use in rural Africa (Chu, 2011; Verma, 2014). This could mean that whilst mitigation strategies are being developed to address gendered concerns these could miss the boat and make no significant or sustained impact on addressing what is accepted as unequal experiences of land grabbing in Africa. This is especially important because of efforts in the literature where studies are trying to undermine the oversimplified homogenous depiction of rural African women experiencing land grabbing as passive and victims. These efforts are commended and are worth building on to address the gap in the current scholarship as it relates to the experiences of women in rural Africa.

Also problematic at present is that studies have either not engaged in sustained grounded research with rural African women or where they have, the voices of experts have been privileged over those whose everyday lived experiences are being directly impacted by the land grabbing phenomenon (Edelman, 2013; Oya, 2013). As I have already mentioned these are being challenged with more grounded research but more is needed to privilege endogenous voices over exogenous ones and significantly enhance our appreciation of the state of rural African women's agency in the midst of the land grabbing phenomenon. It would also have the impact of addressing the actual issues at hand and preventing the potential of conflicts that could disrupt large-scale investments that are needed for the economic empowerment of rural communities in Africa as well as meeting growing global demands for alternative energy and food (Borras, Hall, Scoones, White \& Wolford, 2011; Cotula, 2013; Milgroom, 2015).

\section{Instrumental Case Study Approach}

This research employed semi-structured interviews within an instrumental case study approach to collect data between December 2016 and January 2017 and, April 2017 and June 2017. Thirty residents of Senjeh District and seven key informants participated in the research. A purposive sampling approach was used to select participants. In order to examine the impact of the loss of land the main criteria for inclusion was residents who had lost land to Sime Darby. A modified snowballing technique was incorporated in recruiting participants wherein a participant could only recommend one further person. This was done to avoid all of the participants being from the same social group and skewing the data collected with identical perspectives and experiences. In this paper respondents when quoted are referred to as Respondent followed by a number based on the chronology of their interview. This also applies to key informants. This research received two separate ethical approvals; one from the research institute of the researcher and another from the Institutional Review Board (IRB) of the University of Liberia. Each participant in the research was given an information sheet with details about the project and contact details of the researcher and his supervisors. Participants also signed informed consent forms. The interviews were all recorded on a voice recorder with consent from participants. Once transcribed the recordings were deleted and the transcripts securely saved on Aberystwyth University internal servers. The data was thematically analysed using the Nvivo software.

\section{Divergence of Accounts between Experts and Rural Women}

It was a humid Monday afternoon on 29 May 2017. I had driven to the offices of an international women's NGO in Monrovia, the capital city of Liberia, to interview the head of the organization as part of my research. The organization's main activities involves advocacy for women's rights. Key Informant 2 was very knowledgeable 
and we talked for over three hours. Her responses included a history lesson about gender inequalities in Liberia and particularly as it related to land rights. One of the main take away from my interview with Key Informant 2 was that in her observations of the experiences of women within Senjeh District, they were not party to the prior consultation for the transfer of control over their land to Sime Darby. As she mentioned:

"In terms of land grabs, you have to understand how women use land. Women are the producers in the communities in terms of supplementing household food. Concessions that are being signed would include land that women are already farming on. This is how they are impacted by the process. When decisions are being made it affects women. But they are not involved in the decision making processes." (Key Informant 2)

Clearly, in the experience of Key Informant 2 women in rural communities in Liberia such as Senjeh District were being neglected during the consultation processes. In her view, the experiences of women in Senjeh District aligned with current dominant notions in the land grabbing literature that women were passive and victims who lacked agency (Daley \& Pallas, 2013; Gilfoy, 2014). This was not an isolated notion as it related to my observations whilst in the field. Key Informant 4, an environmental advocate also suggested in his interview with me that he had observed that in rural communities, women were being excluded from the agreements that land grabbers entered into with communities whose land they had taken control over. Making specific reference to Sime Darby he said:

"They claimed to have applied FPIC [free prior informed consent]; for example they said that they speak with the chiefs and enter MOUs. However, the evidence that we have seen shows that the MOUs are entered into with the elites in the communities and not all of the citizens. They sometimes exclude women and youth and, other voluntary groups. There are always conflicts as a result of this and it makes building relationships with the communities and protecting their interest difficult.” (Key Informant 4)

The notion that women are neglected during prior consultations as both Key Informants 2 and 4 mentioned, is a key notion in the literature on the disproportionality of the impacts of land grabbing on rural African women (Chu, 2011; Lund, 2011; Daley \& Pallas, 2013; Doss et al., 2014; Verma, 2014; Martiniello, 2015). The dominant account is that when land deals are about to commence, women are not given a seat at the consultation table and in some cases do not received compensation for crops on the land at the same level as men (De Schutter, 2011; Knight et al., 2012; Daley \& Pallas, 2013; Verma, 2014). The observations of Key Informants 2 and 4 about the experiences of rural women in Senjeh District seem to agree with similar notions in the literature. Both Nyantakyi-Frimpong and Bezner-Kerr (2016) and Verma (2014) argue that rural African women in the cases that they reported on were not given a seat at the consultation table and did not receive compensation for their crops or land lost to land grabbers. Something that they argue undermined the sustainable development rhetoric of large-scale land deals

Whilst Key Informants 2 and 4 as well as some in the literature furthered the narrative that rural African women are not consulted or compensated when they lose control over land to land grabbers, in my experience in Senjeh District that was not the case. Whilst the women that participated in my research claimed that they received no or inadequate compensation, all indicated that they were invited and participated in prior consultation with Sime Darby. Two of the women taking part in my research mentioned:

"Yes. They came and talk to us. We were called, all of us with gardens. We were not given any compensation but they begged us to please move off. They came twice with good intentions but some people said that they could not move because the soil was good. They came back a third time and that is when we were given the 2 month. After the third meeting was when the planes were brought in to spray those crops that people had not taken off." (Respondent 1)

"But for that to happen they came and talked to us. They came and we had workshops. We put ideas together. Some people agreed and some people did not agree. Some people said that the land is for us and our old people made a mistake by giving the land away... They begged us because they did not want any trouble even though they claimed that the land was theirs. We accepted the money they gave because we believed that we had no choice because it could be taken by force if we disagree." (Respondent 14)

Taken in relations to the literature and observations by Key Informants 2 and 4, there are two obvious implications of the divergence with the experiences of women in Senjeh District. Firstly, the divergence from the literature seems to suggest that rural women's experiences of the impacts of land grabbing are not homogenous across Africa. Whilst evidence from studies such as Verma (2014) seem to portray women as not being given a seat at the table, the experiences of women in Senjeh was contrary to that. This suggests that experiences are context specific and any sustainable development effort to try and mitigate challenges that women do face as a result of land grabbing must be developed contextually (Budy, 2020). Secondly, it clearly shows that more needs to be done to capture the endogenous voices of women in rural African communities affected by land grabbing. This is because, as the 
evidence suggests, experts operating in the same context as women participating in my research had divergent views to those women whose everyday lived experiences were being portrayed (Larder, 2015; Oya, 2013). One clarification that is needed before moving on is that I am not saying that by being consulted women had the power to hold the company accountable or achieve sustainable levels of economic development. Some of the same women who told me that they had been consulted also said that they did not received compensation. All I am doing here is providing evidence that women were consulted and participated equitably in the consultation process, which is in disagreement with the current dominant accounts of their experiences in the literature.

\section{Boycotting Employment with Sime Darby}

The suggestion that women are rarely offered employment on large-scale plantations is documented in the literature (De Schutter, 2011; White, 2012; Cotula, 2013; Boamah, 2014). In fact, Cotula (2013) provided evidence to support the notion by arguing that women were mostly offered unsustainable jobs during the early stages of large-scale plantation operations. According to Cotula (2013) the women were offered jobs such as planting crops or weeding. Women were also offered seasonal temporary jobs such as harvesting (Chu, 2011; White, 2012). Relatedly, as De Schutter $(2011,256)$ reported, within the framework of the temporary contractual jobs that some women get 'they are often paid lower than subsistence wages, and are left often without any social or legal protect'.

My observations of how the women in Senjeh District experienced the loss of their land to Sime Darby and the limited and unsustainable employment opportunities available to them seem to agree with both Cotula (2013) and De Schutter (2011). A lot of the women that I spoke with told me that they were rarely offered employment by Sime Darby. In fact, they seemed to confirm what Cotula (2013) said, that most of the jobs that they were offered by Sime Darby were during the initial planting of the oil palm trees and seasonal work during the harvesting of the crops. Respondent 19 mentioned:

"I worked as a contractor for Sime Darby before, helping to plant some of the oil palm you see today. I was expecting to get paid United States (US) \$200 or more but ended up with US\$20.” (Respondent 19)

Just to clarify, the US dollars is used as a legal tender alongside the Liberian dollars. As for Respondent 19, she seemed to confirm the notion in the literature that women in rural places who lose land they depended on for their livelihood needs, were able to access temporary jobs at the start of operations (Chu, 2011; Cotula, 2013). Respondent 19 also seemed to confirm that women who had worked for the company, as suggested by De Schutter (2011), tended to be underpaid for the work that they had undertaken. The suggestion of women being underpaid by Sime Darby for the work that they did for the company was confirmed in other conversations that I had with other women participants in this research. For example Respondent 22 mentioned:

"We went there and worked for 20 days each and we were paid US\$20. They promised that they were going to pay US\$1,020 for the period of the contract but we were only paid US\$20." (Respondent 22)

The narrative that women who had engaged in contractual work with Sime Darby were promised one amount in wages prior to them commencing work and were paid far less than they had been promised was confirmed by multiple women. In a lot of the conversations, the women also told me that they did not receive their wages on time. As such, the literature and experts would have us believe that the women who had been negatively impacted in this way and lacked access to alternative livelihoods to replace the loss of the land were passive and victims, lacking agency (Boamah, 2014; Elhadary, 2010; Vaz-Jones, 2018; Mutopo \& Chiweshe, 2014; Fonjong et al., 2016). Another interesting point to make here is that women in choosing to work for Sime Darby had exhibited empowerment agency (Hartman, 2007).

However, in my experience, the women in Senjeh District were not passive and demonstrated retained agency in the midst of the loss of their land to Sime Darby as well as the unfair treatment that they endured whilst working as temporary contractors for the company. The women came together to exhibit their resistance agency against Sime Darby similar to what we saw in the study by Martiniello (2015) in the Amuru District of Ethiopia. Most of the women that I interviewed, who had worked for the company in some capacity told me that they, exercising their resistance agency, decided to boycott temporary employments from Sime Darby because of their negative experiences. This is something that has received limited attention in the current studies or no attention in the cases of those key informants that I spoke with during my time in the field.

Responding to a question about members of her family working for Sime Darby, Respondent 3 said:

"No. None of my family work for the company. We [women] were called to go and work on a contractual basis but I refused... The money that you get is nothing; US\$30 or US\$20. It is like a waste of time to me. It is better for me to sit down and make my farm, plant my rice and support my children in school." (Respondent 3) 
Also, another respondent - Respondent 20 - mentioned that women had boycotted working for the company because of their experiences. She stated that they could work for Sime Darby 'for months and might not get the full amount' for their labour. This was the experience proffered by many of the women that I spoke with during my time in Senjeh District. The implications of this could be far reaching in terms of what we currently know about how women exhibit their resistance agency to the impacts of land grabbing in Africa. Firstly, the fact that the evidence here diverge from the narratives in the literature and expert knowledge of those in the field suggests that the oversimplified homogenous depiction of all rural African women's experiences is problematic. Depicting women as passive victims who lack agency would continue to undermine developmental objectives by developing mitigation strategies that do little if anything to address the plight of rural African women negatively experiencing the impacts of land grabbing. As such, policy makers must go beyond what is already known and prioritize deeper engagements with rural African women.

Secondly, the methodological approach adopted in this research is key to unearthing context specific experiences of women in the midst of land grabbing as well as enhance our understanding of the ways and reasons that rural women in Africa exhibit agency against the negative impacts of the phenomenon (Edelman, 2013; Oya, 2013). This suggests that the focus of future research must prioritize sustained grounded approaches of a qualitative nature. They must also seek to privilege the endogenous voices of women over the exogenous voices of experts in order to ensure positive sustainable development outcomes for women in particular and rural communities in general (Edelman, 2013; Oya, 2013; Budy, 2020).

\section{Women's Diverse and Alternative Livelihood Decisions}

Diversifying their livelihood activities to contribute to household livelihood needs is something that is well documented in the literature on the impacts of land grabbing on rural African women (Ossome, 2014; Murphy et al., 2017; Ryan, 2017). Both Cotula (2013) and Boamah (2014) have demonstrated how women were responsible for the cultivation of domestic crops to be used by their families and would grow crops on smaller plots of land to supplement the livelihood needs of their families. Also, as Murphy et al. (2017) suggest, losing their land to land grabbers forced some women in rural Africa to exhibit instrumental agency by shifting from the cultivation of crops to more market-based activities such as selling theirs and their children's labour as well as brewing and selling local beer as ways to mitigate the negative impacts of losing their land. These evidence highlight that there is a growing appreciation of the fact that women in rural communities in Africa, affected by land grabbing are exhibiting various types of agency when shifting or diversifying their livelihood activities to sustain their families (Burns et al., 2010; Ossome, 2014; Murphy et al., 2017).

Whilst some in the literature have highlighted the fact that rural African women are involved in livelihood activities to supplement the livelihood needs, they discuss these in terms of purely necessity than a demonstration of agency by individual women (Knight et al., 2012; Cotula, 2013; Murphy et al., 2017; Ryan, 2017). My observations in Senjeh District suggest that the decisions and actions by women in undertaking diverse, or alternative, livelihood activities were a demonstration of their instrumental agency in the midst of necessity (Hall et al., 2015). In fact, in my observations the women involved in diverse or alternative, livelihood activities, whilst doing so out of necessity, were exhibiting instrumental agency. For example, Respondent 1 mentioned that:

"The company does not pay our men on time so we [women] use the money from the garden to support the family before our men get paid... Farming crops like cassava, potato leaves, peppers, egg plants, eddos and sugarcane and, taking them to Gbah to sell and buy things for the house because Sime Darby does not pay on time. I did not want to sit and wait for my husband. So, I manage the income from the sale of the crops to support my family until my husband takes his pay." (Respondent 1)

One of the key observations from my conversation with Respondent 1 was the fact that she was aware that she had lost land to Sime Darby and that it had negative outcomes. However, she exhibited instrumental agency by using the negative experience of losing land to the company to engage in the cultivation of alternative crops to support her husband who in some way was exhibiting empowerment agency by working for Sime Darby (Wolkomir, 2004; Mir, 2009). She also suggested that this was an exhibition of agency that other women in the district were involved in. In fact, in conversations with other women who had made similar decisions and acted to supplement their family's income, they confirmed that this was something that a lot of women did. Furthermore, from my experience in Senjeh the decisions to act were made by women themselves (Hall et al., 2015; Ryan, 2017). Whilst it has been argued that women were doing these activities out of necessity (Murphy et al., 2017), in the case of Senjeh District, acting out of necessity did not diminish the fact that they were exhibiting instrumental agency in the process of responding out of necessity. This is because not every woman whose husband worked for Sime Darby was involved in alternative or diverse livelihood activities. There were some women that I encountered that did not grow crops 
like Respondent 1 to sell in Gbah to buy things for their family because the husband's wages were delayed. Furthermore, the decision to supplement their families' income was not always as a result of delays in their husbands getting their wages. As Respondent 2 stated some people wanted the extra income.

"Some of the people who work for the company also have farms to supplement their income to provide enough for their family." (Respondent 2)

Likewise, it was not only women with husbands who worked for Sime Darby that had to diversify their livelihood activities to support their families. The husbands of both Respondents 3 and 17 did not have employments with Sime Darby but both were also involved in alternative livelihood activities to support their families.

"I have joined a Susu [a rural saving scheme] with some of my friends. I put money in regularly from selling potato leaves from the garden. When I get the money from the Susu I invest that in buying provisions to sell in the town." (Respondent 3)

"As for me I am now a petty trader. We depended on the potato leaves from the gardens to sell and raise money to send our children to school and buy other essentials. Now that they have destroyed them we have to go to other towns to buy potato leaves and take it to the market to sell and the profit we make on that goes towards taking care of the family." (Respondent 17)

The husbands of both Respondent 3 and 17 were unemployed. What is important to note here is that both Respondent 3 and 17 were clear in their responses to me that they were involved in alternative livelihood activities because they made the decision to do so and not because they had been acted upon. Furthermore, they also chose the activities that they were involved in and not others that were available. Respondent 3 had the option of working for the company but was one of the women who had boycotted Sime Darby. Key here, is that these fresh perspectives adds to the growing body of work catering to evidence of rural African women as having agency in the midst of land grabbing (Hall et al., 2015; Martiniello, 2015; Moreda, 2015; Ryan, 2017; Budy, 2020). It adds novel understandings of the various agency being exhibited by rural women and stresses the need for more context specific grounded research that privilege endogenous voices over exogenous ones.

\section{Shifting Crops Cultivated as Demonstration of Reactions}

As we might now be aware the oversimplification of the experiences of the impacts of land grabbing on women in rural communities in Africa is a mainstay in the current literature (Borras et al., 2013; Edelman, 2013; Oya, 2013; Larder, 2015; Edelman \& Borras, 2016; Vieri \& Calabro, 2019; Budy, 2020). However, as some studies challenging those accounts have shown, individuals within rural communities are not homogenous in their experiences of land grabbing (Cotula, 2013; Hall et al., 2015; Larder, 2015; Edelman \& Borras, 2016; Murphy et al., 2017). Factors such as context, influence of exogenous actors, social status as well as individual personalities are all factors that could influence how women experience losing their land to land grabbers (Verma, 2014; Hall et al., 2015; Murphy et al., 2017; Ryan, 2017).

The evidence from my experience in Senjeh District seem to agree with the notions in the literature that women experienced the impacts of land grabbing in different ways (Chu, 2011; Ryan, 2017). Clearly, the discussion in the previous section about women with husbands contributing to their families' livelihoods contributes to demonstrating that notion. Some women making decisions to supplement their family's livelihood had husbands working for the company whilst others had husbands who were unemployed. In the same way other women, both those with husbands and those without husbands, demonstrated various agency in terms of decisions about how they responded to losing their land to Sime Darby. In conversations, women talked about the fact that the land that they lost was close to a river called Mahe. Access to the river, prior to losing the land to Sime Darby, enabled residents, including the women to sustainably cultivate rice. This is how Respondent 19 mentioned it to me:

"We grew rice on the land. We harvested the rice for eating. We did not sell all of the rice. Our parents did not want us to suffer so when we harvested the rice we would keep it in the kitchen for eating. We would only take some out as seeds to be used in the next year for planting." (Respondent 19)

However, as the women explained to me, once they lost the land to Sime Darby, the scarcely available land did not have the same access to water for the cultivation of rice. As such, most of the women told me that they shifted the crops they cultivated from rice to cassava. Cassava is a drought resistant crop that is used as a substitute for rice in communities where the cultivation of rice is difficult due to drought or land grabbing (Burns et al., 2010). Confirming the exhibition of instrumental agency in shifting the crops cultivated in response to the loss of the land near the Mahe River, Respondent 26 stated:

"It is cassava that I do now.... When I harvest the cassava I make Fufu and Gari and sell them to get money." (Respondent 26) 
Gari is a powder and Fufu a puree made from cassava. In terms of exhibiting instrumental agency, there was no doubt from the conversations that I had with the women in Senjeh District that they had made the decisions to cultivate cassava on the available land. Respondents 9 and 24 unlike most of the women that I spoke with did not have husbands. They told me that they too had lost land close to the river, which they used for the cultivation of rice and that they were now cultivating cassava on the available land that they had access to. The women, those with or without husbands, told me that it was their decision to shift the crops that they were cultivating. For those without some of the scarcely available land, they produced charcoal from wood collected from the forest, selling it to generate income. The main implication here is that whilst the literature has evidence that suggests that rural African women who lose land diversify or shift their livelihood activities purely out of necessity, these have not always discussed this as exhibition of instrumental agency. In the case of Senjeh District in Liberia, whilst the women decided to diversify their livelihood activities to make ends meet, they did so with options. Firstly, some women chose to cultivate cassava on the land instead of more domestic crops like garden eggs, peppers and okra. As they explained to me, it was because of the multiple uses of the cassava. They chose to cultivate cassava because they could modify it into Gari or Fufu which they sold to earn money. Also, some women told me that their choice of cassava was strategic because it could be stored in their available storage for a long period of time without it rotting.

Secondly, not all of the women made the same choices. For at least of the women, she did not have to do anything to support her family. As she would tell me, that was the responsibility of her partner. According to Respondent 19 who told me:

"My family people are helping me with the children. I have a boyfriend here who helps me as well. I am not working." (Respondent 19)

This is another example that undermines the oversimplification of the experiences of rural women in Africa in the midst of land grabbing. Just to be clear, for most of the other women who participated in this research, they too had childcare and partners. However, that did not deter them from demonstrating various agency in the actions that they took to contribute to the livelihood needs of their families by shifting to the cultivation of cassava which was more suited to the available land that they had, or gathering wood from the forest to produce charcoal to sell. Also, whilst at the time of her interview Respondent 19 exhibited a kind of compliant agency to the patriarchal structures by not being engaged in livelihood activities tied to the land, she had been involved at some point as her earlier comments suggested. The main implication here is that rural women in Senjeh were not passive and made strategic decisions which had sustainable developmental outcomes for themselves and the wider community. The evidence demonstrates that women made the decisions, unaided, to shift or diversify their livelihood activities.

\section{Conclusion}

The aim of this paper is to make an empirical contribution to our appreciation of rural African women's retained agency in the midst of land grabbing by bringing fresh perspectives to the debate and build on the growing body of literature challenging current accounts of rural African women being passive and victims who lack the agency to react against the loss of control over their land. To this end, there are two key conclusions that this paper draws. Firstly, there is divergence between the dominant narratives in the current accounts of women's experiences of land grabbing and the actual everyday lived experiences of women on the ground, which has the potential to undermine sustainable development efforts. This paper demonstrated that in Senjeh District, there was a clear divergence between key informants and the literature on the one hand and, women who had experienced the loss of land to Sime Darby on the other. It was clear that whilst the experts' narratives seemed to agree with the literature, the lived experiences of women in Senjeh District differed. Whilst experts presented women as not being consulted or compensated, passive and victims that lacked agency, the women that participated in this research recounted their experiences differently. This suggests that experiences and reactions to land grabbing are context specific and requires sustained grounded research that privileged endogenous knowledge over exogenous ones. It also suggests that privileging the voices of endogenous actors in rural spaces in Africa is crucial to any sustainable development agenda being developed. In presenting this argument this paper confirms the robustness of similar arguments in the studies that this paper is building on.

The second conclusion which has been drawn from the evidence presented in this paper is that for the women of Senjeh District who had lost their land to Sime Darby they demonstrated that they were not passive or victims as some would want us to believe but that they retained their agency in the midst of the phenomenon. This was done through the demonstration of various agency - resistance, empowerment, instrumental and compliant. The women also demonstrated that they could exhibit their various agency in a variety of ways. Collectively the women boycotted employment with the company because of the negative experiences of working for the company. The 
women also demonstrated their agency by deciding to and undertaking alternative livelihood activities to supplement their families' incomes in the case of those in two adults' households, or as the main source of livelihood for women without a husband. Yet, the women also shifted from the cultivation of rice to a more drought resistant crop - cassava - or charcoal production for those who did not have a plot of land on which to cultivate crops. This means that developmental strategies intended to mitigate the inequalities in experiences of men and women in the midst of land grabbing must account for the fact that rural women affected by land grabbing retain agency and have demonstrated their various agency to react against the loss of their land in a variety of ways. As such, mitigation efforts must privilege the endogenous knowledge of rural African women in policy development.

Whilst this paper has provided fresh perspectives on the experiences of rural women who had lost their land to Sime Darby, it is limited in the sense that the knowledge gained, whilst shedding new lights on how women experience land grabbing, is context specific. The arguments in this case can only be applied in other similar contexts. This means that for future researchers, more sustained grounded approaches to research that privilege the endogenous knowledge of rural African women affected by land grabbing would be required.

\section{Acknowledgements}

I would like to thank all of the lovely people of Senjeh District for trusting me to tell their stories to the world. I would also like to acknowledge the generous support provided to this research by the Global-Rural Project team based at Aberystwyth University, my research assistant in Liberia as well as colleagues within the Department of Geography and Earth Sciences at Aberystwyth University.

\section{References}

Archambault, C. S., \& Zoomers, A. (Eds.). (2015). Global trends in land tenure reform: Gender impacts. London: Routledge.

Behrman, J., Meinzen-Dick, R., \& Quisumbing, A. (2012). The gender implications of large-scale land deals. Journal of Peasant Studies, 39(1), 49-79. https://doi.org/10.1080/03066150.2011.652621

Bilge, S. (2010). Beyond subordination vs. resistance: An intersectional approach to the agency of veiled Muslim women. Journal of intercultural studies, 31(1), 9-28. https://doi.org/10.1080/07256860903477662

Boamah, F., (2014). Imageries of the contested concepts "land grabbing" and "land transactions": Implications for biofuels investments in Ghana. Geoforum, 54, 324-334. https://doi.org/10.1016/j.geoforum.2013.10.009

Borras Jr, S. M., Franco, J. C., \& Wang, C. (2013). The challenge of global governance of land grabbing: changing international agricultural context and competing political views and strategies. Globalizations, 10(1), 161179. https://doi.org/10.1080/14747731.2013.764152

Borras Jr, S. M., Hall, R., Scoones, I., White, B., \& Wolford, W. (2011). Towards a better understanding of global land grabbing: an editorial introduction. The Journal of Peasant Studies, 38(2), 209-216. https://doi.org/10.1080/03066150.2011.559005

Budy, F. C. T., (2020). Political reactions from below to Sime Darby land grab: Generational shift, geographical reach, rural influencers and multi-stakeholder alliance. Journal of Rural Studies, 76, 193-201. https://doi.org/10.1016/j.jrurstud.2020.04.007

Burke, K. C. (2012). Women's agency in gender - traditional religions: A review of four approaches. Sociology Compass, 6(2), 122-133. https://doi.org/10.1111/j.1751-9020.2011.00439.x

Burns, A., Gleadow, R., Cliff, J., Zacarias, A., \& Cavagnaro, T. (2010). Cassava: the drought, war and famine crop in a changing world. Sustainability, 2(11), 3572-3607. https://doi.org/10.3390/su2113572

Chapelle, S. (2014). Live or drive, a choice has to be made: A case study of Sime Darby Operations in Liberia. Friends of the Earth. Basta.

Chu, J. (2011). Gender and 'Land Grabbing in Sub-Saharan Africa: Women's land rights and customary land tenure. Development, 54(1), 35-39. https://doi.org/10.1057/dev.2010.95

Corson, C., Brady, B., Zuber, A., Lord, J., \& Kim, A. (2015). The right to resist: Disciplining civil society at Rio+ 20. Journal of Peasant Studies, 42(3-4), 859-878. https://doi.org/10.1080/03066150.2014.992884

Cotula, L. (2013). The great African land grab? Agricultural investments and the global food system. London: Zed Books Ltd.

Cotula, L., Vermeulen, S., Leonard, R., \& Keeley, J. (2009). Land Grab or Development Opportunity? Agricultural Investments and International Land Deals in Africa. Rome: FAO, IFAD, IIED. 
Daley, E., \& Pallas, S. (2013). Women and land deals in Africa and Asia: Weighing the implications and changing the game. Feminist Economics, 20(1), 178-201. https://doi.org/10.1080/13545701.2013.860232

Damtew, S. G., (2019). Land-grabbing and the right to adequate food in Ethiopia. African Human Rights Law Journal, 19(1), 219-245. https://doi.org/10.17159/1996-2096/2019/v19n1a11

De Schutter, O., (2009). Report of the Special Rapporteur on the Right to Food, Olivier De Schutter: Large-scale Land Acquisitions and Leases - A Set of Minimum Principles and Measures to Address the Human Rights Challenge. Human Rights Council Thirteenth Session Agenda Item 3, A/HRC/13/33/Add.2, United Nations.

De Schutter, O., (2011). How not to think of land-grabbing: three critiques of large-scale investments in farmland. The Journal of Peasant Studies, 38(2), 249-279. https://doi.org/10.1080/03066150.2011.559008

Doss, C., Summerfield, G., \& Tsikata, D. (2014). Land, gender, and food security. Feminist Economics, 20(1), 123. https://doi.org/10.1080/13545701.2014.895021

Edelman, M., \& Borras, S. M. (2016). Political Dynamics of Transnational Agrarian Movements. Warwickshire: Fernwood Publishing.

Edelman, M., (2013). Messy hectares: questions about the epistemology of land grabbing data. Journal of Peasant Studies, 40(3), 485-501. https://doi.org/10.1080/03066150.2013.801340

Elhadary, Y. A. E., (2010). Challenges facing land tenure system in relation to pastoral livelihood security in Gedarif State, Eastern Sudan. Journal of Geography and Regional Planning, 3(9), 208-218. https://doi.org/10.9734/jsrr/2015/11344

Fonjong, L., Sama-Lang, I., Fombe, L., \& Abonge, C. (2016). Land governance and women's rights in large-scale land acquisitions in Cameroon. Development in Practice, 26(4), 420-430. https://doi.org/10.1080/09614524.2016.1162285

Gilfoy, K. (2014). Land grabbing and NGO advocacy in Liberia: A deconstruction of the 'homogeneous community'. African Affairs, 114(455), 185-205. https://doi.org/10.1093/afraf/adu078

Gingembre, M. (2015). Resistance or participation? Fighting against corporate land access amid political uncertainty in Madagascar. Journal of Peasant Studies, 42(3-4), 561-584. https://doi.org/10.1080/03066150.2015.1022867

GRAIN. (2008). Seized! The 2008 land grab for food and financial security. Grain Briefing. Barcelona: GRAIN.

Hall, R., Edelman, M., Borras Jr, S. M., Scoones, I., White, B., \& Wolford, W. (2015). Resistance, acquiescence or incorporation? An introduction to land grabbing and political reactions 'from below'. Journal of Peasant Studies, 42(3-4), 467-488. https://doi.org/10.1080/03066150.2015.1036746

Hartman, T. (2007). Feminism encounters traditional Judaism: Resistance and accommodation. Waltham, MA: Brandeis University Press.

Hausermann, H., Ferring, D., Atosona, B., Mentz, G., Amankwah, R., Chang, A., Hartfield, K., Effah, E., Yeboah Asuamah, G., Mansell, C., \& Sastri, N. (2018). Land-grabbing, land-use transformation and social differentiation: Deconstructing "small-scale" in Ghana's recent gold rush. World Development, 108, 103-114. https://doi.org/10.1016/j.worlddev.2018.03.014

Haywood, L., von Maltitz, G., Setzkorn, K., \& Ngepah, N. (2008). Biofuel production in South Africa, Mozambique, Malawi and Zambia: A status quo analysis of the social, economic and biophysical elements of the biofuel industry in Southern Africa." Natural Resources and the Environment. Pretoria: CSIR.

Knight, R., Adoko, J., Auma, T., Kaba, A., Salomao, A., Siakor, S., \& Tankar, I. (2012). Protecting community lands and resources: Evidence from Liberia, Mozambique and Uganda. Rome: Namati and International Development Law Organisation (IDLO).

Larder, N. (2015). Space for pluralism? Examining the Malibya land grab. Journal of Peasant Studies, 42(3-4), 839-858. https://doi.org/10.1080/03066150.2015.1029461

Lund, C. (2011). Land rights and citizenship in Africa. Uppsala: Nordiska Afrikainstitutet.

Malunga, C., \& Holcombe, S. (2016). Endogenous Development: Naïve Romanticism or Practical Route to Sustainable African Development. https://doi.org/10.4324/9781315676616

Martiniello, G., (2015). Social struggles in Uganda's Acholiland: understanding responses and resistance to Amuru sugar works. Journal of Peasant Studies, 42(3-4), 653-669. https://doi.org/10.1080/03066150.2015.1032269 
Milgroom, J. (2015). Policy processes of a land grab: At the interface of politics 'in the air' and politics 'on the ground' in Massingir, Mozambique. Journal of Peasant Studies, 42(3-4), 585-606. https://doi.org/10.1080/03066150.2014.991721

Mir, S. (2009). Not too "college - like," not too normal: American Muslim undergraduate women's gendered discourses. Anthropology \& Education Quarterly, 40(3), 237-256. https://doi.org/10.1111/j.15481492.2009.01043.x

Moreda, T. (2015). Listening to their silence? The political reaction of affected communities to large-scale land acquisitions: insights from Ethiopia. Journal of Peasant Studies, 42(3-4), 517-539. https://doi.org/10.1080/03066150.2014.993621

Murphy, S., Carmody, P., \& Okawakol, J. (2017). When rights collide: land grabbing, force and injustice in Uganda. The Journal of Peasant Studies, 44(3), 677-696. https://doi.org/10.1080/03066150.2016.1259616

Mutopo, P. (2011). Women's struggles to access and control land and livelihoods after Fast Track Land Reform in Mwenezi District, Zimbabwe. Journal of Peasant Studies, 38(5), 1021- 1046. https://doi.org/10.1080/03066150.2011.635787

Mutopo, P., \& Chiweshe, M. (2014). Large-scale land deals, global capital and the politics of livelihoods: Experiences of women small-holder farmers in Chisumbanje, Zimbabwe. International Journal of African $\begin{array}{llll}\text { Renaissance } \quad \text { Studies-Multi-, } & \text { Inter-and } \quad \text { Transdisciplinarity, } & 9(1), & \text { 84-99. }\end{array}$ https://doi.org/10.1080/18186874.2014.916879

Ndi, F. A. (2019). Land grabbing: A gendered understanding of perceptions and reactions from affected communities in Nguti Subdivision of South West Cameroon. Development Policy Review, 37(3), 348-366. https://doi.org/10.1111/dpr.12351

Nyantakyi-Frimpong, H., \& Bezner Kerr, R. (2016). Land grabbing, social differentiation, intensified migration and food security in northern Ghana. The Journal of Peasant Studies, 44(2), 421-444. https://doi.org/10.1080/03066150.2016.1228629

Ossome, L. (2014). Can the law secure women's rights to land in Africa? Revisiting tensions between culture and $\begin{array}{llll}\text { land commercialization. } & \text { Feminist }\end{array}$ https://doi.org/10.1080/13545701.2013.876506

Oya, C. (2013). Methodological reflections on 'land grab' databases and the 'land grab' literature 'rush'. Journal of Peasant Studies, 40(3), 503-520. https://doi.org/10.1080/03066150.2013.799465

Peemans, J. (2014). Land grabbing and Development history: The Congolese (RDC) experience. Losing your land: Dispossession in the Great Lakes. London: James Currey: 11-35.

Razavi, S. (2003). Introduction: Agrarian change, gender and land rights. Journal of Agrarian Change, 3(1\&2), 232. https://doi.org/10.1111/1471-0366.00049

Ryan, C. (2017). Large-scale land deals in Sierra Leone at the intersection of gender and lineage. Third World Quarterly, 39(1), 189-206. https://doi.org/10.1080/01436597.2017.1350099

Siakor, S. K. (2012). Uncertain futures: The impacts of Sime Darby on communities in Liberia. World Rainforest Movement, Montevideo, Uruguay.

Tsikata, D., \& Yaro, J. A. (2014). When a good business model is not enough: Land transactions and gendered livelihood prospects in rural Ghana. Feminist Economics, 20(1), 202-226. https://doi.org/10.1080/13545701.2013.866261

Tzouvala, N. (2019). A false promise? Regulating land-grabbing and the post-colonial state. Leiden Journal of International Law, 32(2), 235-253. https://doi.org/10.1017/s0922156519000128

Unruh, J. D. (2009). Land rights in postwar Liberia: the volatile part of the peace process. Land Use Policy, 26(2), 425-433. https://doi.org/10.1016/j.landusepol.2008.05.005

Vaz-Jones, L. (2018). Struggles over land, livelihood, and future possibilities: Reframing displacement through feminist political ecology. Signs, 43(3), 711-735. https://doi.org/10.1086/695317

Verma, R. (2014). Land grabs, power, and gender in East and Southern Africa: So, what's new? Feminist Economics, 20(1), 52-75. https://doi.org/10.1080/13545701.2014.897739 
Vermeulen, S., \& Cotula, L. (2010). Over the heads of local people: consultation, consent, and recompense in large-scale land deals for biofuels projects in Africa. The Journal of Peasant Studies, 37(4), 899-916. https://doi.org/10.1080/03066150.2010.512463

Vieri, S., \& Calabro, G. (2019). Food Security and Land Grabbing in Low-Income Countries of the Sub-Saharan Africa. Quality-Access to Success, 20(172), 118-125. http://dx.doi.org/10.21272/sec.3(4).72-85.2019

White, B. (2012). Agriculture and the generation problem: rural youth, employment and the future of farming. IDS Bulletin, 43(6), 9-19. https://doi.org/10.1111/j.1759-5436.2012.00375.x

Wisborg, P. (2013). Human rights against land grabbing? A reflection on norms, policies, and power. Journal of Agricultural and Environmental Ethics, 26(6), 1199-1222. https://doi.org/10.1007/s10806-013-9449-8

Wolkomir, M. (2004). "Giving it up to God" Negotiating Femininity in Support Groups for Wives of Ex-Gay Christian Men. Gender \& society, 18(6), 735-755. https://doi.org/10.1177/0891243204268772

\section{Copyrights}

Copyright for this article is retained by the author(s), with first publication rights granted to the journal.

This is an open-access article distributed under the terms and conditions of the Creative Commons Attribution license (http://creativecommons.org/licenses/by/4.0/). 